\title{
An overview on green human resource management practices
}

\author{
Asmaa Sabry AbdAlaziz Salama Radwan \\ Amira Sayed Mohamed Gadelrab \\ Suez Canal University, Egypt \\ Ghadeer Mohamed Badr ElDin Aboul Ela \\ Future University in Egypt
}

\section{Keywords}

Green Human Resource Management, Green Job Analysis, Green Recruitment and Selection, Green Training and Development.

\begin{abstract}
In accordance with growing awareness towards a global sustainable better future and the United Nations sustainable development goals (SDGs), the concept of Green Human Resource Management Practices became the wheel for driving organizational sustainability and growth. In this respect, scholars have attempted to investigate and analyze the dimensions and pillars of Green Human Resource Management Practices. This paper introduces an overview on the Green Human Resource Management Practices including green job analysis, green recruitment and selection as well as green training and development. This research analyzes the selected practices through addressing the extant literature as well as presenting an analysis of the previous studies. Conclusion is addressed to analyze the findings from the viewpoint of the researchers.
\end{abstract}

\section{Introduction}

In the late of 19th-Century the world has Insight into the psychology of color and emotion. Therefore, many scientists such as Carl Jung and Nei Ching devoted themselves for studying the psychology of colors, and they are ardent and have researched a lot about green color meaning and psychology. Particularly in color psychology, the green color affects our thinking and our physical health in a positive way. Additionally, it is a commanding color in nature that makes you think of growth. Besides, green is a color that can arouse impressive emotions, thinking of nature and seeing the inconceivable variety of shades of green expressing regeneration and enthusiasm.

As consequence, in 1993 the term "Green Business" was coined and spread by the scientist Schott and Fischer. They have edited one of the most deliberate academic literatures on green business. Green business is also known as smart business. Therefore, green business can be expressed as business exercises and practices that are employed to be eco-friendly.

Moving over to green human resource management (GHRM), there has always been confusion in articles as to whether GHRM is 'familiar' term to most of academicians or that it can be 'unfamiliar' to them. However, (Opatha, 2013) confirmed that it is rather hard to convert the whole organization green. That is the cause why HR practices are an essential part of sustainable business evolution. Moreover, (Stojanoska, 2016) defined GHRM as a part of human resource management that is participating with transforming the regular workforce into a green workforce regarding the objective of achieving the environmental targets of the company.

Green human resource management is associated with the practices, frameworks, and actions that help in guiding the workforce of a company into the green transforming for the interest of human, ecosystem, community, and the organization. This paper discusses GHRM practices represented in, Green Job Analysis, Green Recruitment and Green Training and Development. It will focus on the objectives and techniques of each process and in particular that are applicable to green hotels in Egypt.

\section{Literature Review}

\section{Green Human Resource Management Practices}

Green human resource management practices have been identified as a direct function of green management. (Halawi and Zaraket, 2018) stressed that green human resource management's objective is 
to support an organization in carrying out its green management plan in order to bring down its ecological footprint and achieve human welfare. Within this framework, green human resource management establishes organizational green strategy goals, and motivates workforces to be ecologically sustainable, skilled, ethically aware, and driven to create eco-friendly work atmosphere (Bombiak and Kluska, 2018)

In the quintessence, the main objective of implementing green human resource management is to adjust the broader organizational framework to ensure its long-term viability (i.e., workforces, atmosphere, and practices). Furthermore, long-term green human resource management provides social, human, and ecological consequences and contributes to lengthy sustainability organizations.

Besides, (Luo, Zhang, and Zhao, 2020) investigated how GHRM practices affect staffs' green behavior. Workers' life span, learning and education, employee participation, and leaders' engagement all significantly contribute green performance, but incentives only indicate extra-role activity in the longterm. On the other hand, several researchers such as Stoliaruk, Vasylyk and Tsymbaliuk explored green human resource management-related topics in 2021. Some research looks into the level of green human resource management practices throughout various types of employees, including human resources specialists from diverse organizations.

The studies of Zahid and Jamal reveal that, despite widely spread knowledge, green human resource management practices are remaining uncommon. In that case, organizations desire to apply the green human resource management practice in the long term. Eventually, this research in the field of GHRM are devoted to practices of implementation of GHRM into different HRM functions such as, green job analysis, green recruitment and selection, and green training and Development.

\section{Green job analysis}

Initially, it is very important for most Human Resource professionals to know the specifics of the job. Therefore, Information about jobs and their requirements are composed through a process known as job analysis. Besides, job Analysis process is considered the backbone of the most human resource practices, wherein a number of functions can be rendered.

In general, job analysis is expressed as the process of collecting and scrutinizing information about job descriptions and specifications, in addition determining the qualifications needed to perform the job efficiently. Moreover, (Muaf and Wijayani, 2015) defined Job analysis as the process that includes the gathering data activities, which is pointedly concerned with job description, job specifications, and job standards.

However, (Juneja, 2015) affirmed that Job analysis process plays a fundamental role in organizations, which is how the organization uses job analysis data in Workforce planning, Performance analysis, Recruitment and selection, Training and development, Compensation management, Health, safety and security, Employee/labor relations and Risk management. The following figure (1) chooses the purpose of job analysis as illustrated above.

Figure 1: Purpose of Job Analysis

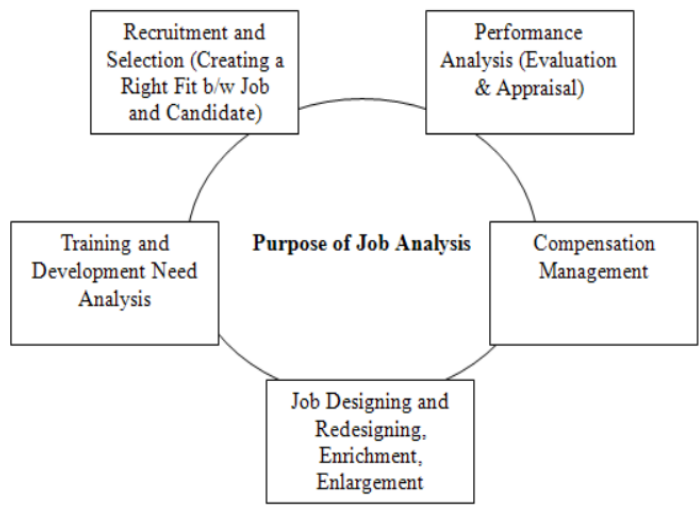

Source: Management Study Guide. (2015). Job Analysis - Job Description and Job Specification.

https://www.managementstudyguide.com/job-analysis.htm. 
Moving over green job analysis, several organizations have designed new green jobs or positions in order to concentrate particularly on eco-friendly management prospects of the organizations. Whether, green job can be defined as a decent job that participate to conserve the environment, (International Labour Organization (ILO), 2016). For the ILO, green jobs are all those jobs that located in the dashed area as illustrated by the diagram below (figure 2).

Figure 2: Total employment

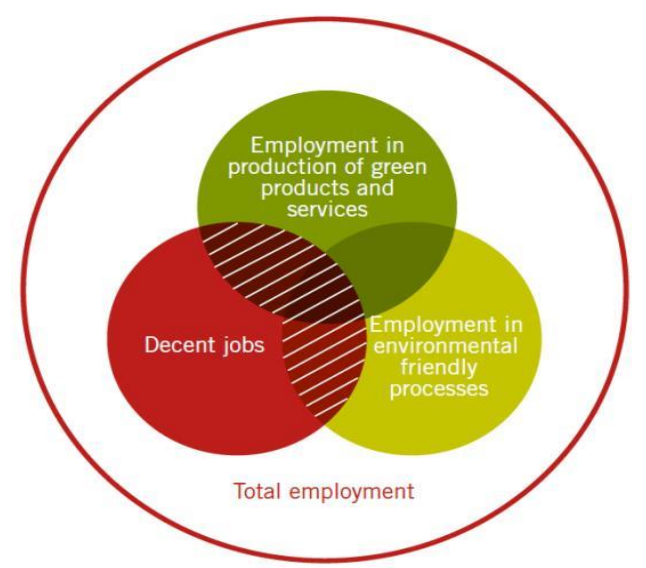

Source: International Labour Organization (ILO). (2016). Green jobs. https:// www.ilo.org/global/topics/green-jobs/lang--en/index.htm

Additionally, from the viewpoint of Human Resource Management, it is truly a precious objective to safeguard the environment. Therefore, some organizations have involved in designing their existing jobs in a more environmentally friendly style by merging environmental focused duties and responsibilities.

Besides, (Tipoe, Kuralbayev and Bowen, 2018) mentioned in their work that green jobs diversify in usage and importance of green tasks, with not many jobs embracing solely green tasks, they nominated that the term 'green' have to be regarded as a continuum in preference to a binary characteristic. Greening is likely to encompass transitions on a similar standardize and range of present job transitions. Although it is easier to go green indirectly in preference to green jobs directly, only a few skill-specific traits for nongreen jobs seem to distinguish them from their green counterparts. Accordingly, the majority of retraining can take place on the job. (Tipoe, Kuralbayev and Bowen, 2018).

According to "ONET Resource Center" Green jobs are characterized as any occupation that will be influenced by greening, and there are three subcategories of green occupations based on the impact of greening on the duties, skills, and knowledge required for the job:

Green Increased Demand (Green ID) are Existing jobs that are likely to be in high demand by cause of greening, but do not require major changes in duties, skills, or knowledge. These jobs are termed "indirectly green" since they assist green economic activity without requiring any green tasks.

Green Enhanced Skills (Green ES) are Existing jobs that, by cause of greening, require considerable changes in duties, skills, and knowledge

Green New and Emerging (Green NE) are unexampled and unique jobs (as defined by workforce requirements) were created to accommodate the new needs of the green economy

As a consequence, in 2019 came the work of Sayeed, Khan and Majeed who identified Green Job Design and Analysis as the process of creating and implementing new, unexampled and unique jobs and positions that are completely focused on the organization's environmental management aspects. It requires merging many environmental protection-related tasks, responsibilities, and duties into each job. In addition, (Sayeed, Khan and Majeed, 2019) mentioned that (Opatha, 2016) stated in his work that, inclusion of environmental dimension as a duty in job description and simultaneously incorporating green competencies as an absorbing constituent in job specification comes under the preview of green job analysis. Moreover, they pointed out that many organizations have begun to adopt such environmentally friendly practices in order to protect the environment. Each job description has come to incorporate at 
least one duty relevant to environmental protection, as well as specific environmental duties. (Al Mamun, 2019) discussed green job design and analysis practices as:

Including a variety of environmental-related activities, obligations, and responsibilities in each employment and putting them into practice.

Including a variety of environmental-related activities, obligations, and responsibilities in each employment and putting them into practice.

Including as many environmental, social, personal, and technical requirements as possible in work descriptions and person (job) specifications and putting them into practice.

Using job design strategies like as cooperation and cross-functional teams to successfully manage the company's environmental challenges.

Incorporating the environmental dimension as a job requirement. Including green skills as a distinct component in job descriptions.

Designing and executing new occupations and positions to focus solely on the organization's environmental management components.

Besides, the work of (Sobih, 2019) who stated that Job analysis includes job descriptions and job specifications that should have a green approach in order to apply GHRM. As mentioned before, the requisite skills, knowledge, and abilities for each position should be included in the job specification to ensure that the environment obligations are met. Moreover, environmental responsibilities should be included in the job description.

The following points illustrates some green practices introduced by (Arulrajah, Opatha, and Nawaratne, 2015)

Including a variety of environmental-related tasks, duties, and responsibilities in each job and putting them into a collection.

As far as possible, including environmental, social, personal, and technical requirements of companies in job descriptions and person specifications, and putting them into practice.

Using job design strategies such as cooperation and cross-functional teams to successfully manage the company's environmental challenges.

Incorporating the environmental dimension as a job need.

Including green skills as a distinct component in job descriptions.

Eventually, Work and nature are inextricably linked. The future is reliant on the natural environment. A healthy earth is necessary for our jobs and organizations. Therefore, green human resource management practices (i.e., green job analysis, green recruitment and green training and development.) strongly support The Sustainable Development Goals (SDGs) 2030 Agenda and Egypt's Vision 2030. In line with the 2030 Agenda, the Egyptian Government has established a working plan named Egypt's Vision 2030, also known as Sustainable Development Strategy (SDS).

The SDS encourages economic growth based on equity, social integrity, and engagement. All development plans in Egypt are incorporated into the SDS, which is also significantly directed by the SDGs. Therefore, green human resource management practices aligned with the third sustainable development goal (Good Health and Well-Being) and eighth sustainable development goal (Decent Work and Economic Growth) through green practices such as ecological preservation, pollution protection, prevention practices (i.e., waste data collection and pollution source identification), reduction and waste management, and workforce training in green workplace analysis.

However, only because the employee works in the green organization does not guarantee he has a green job, there must be clear job specifications and job descriptions in the organization. Therefore, numerous hotels use job techniques such as cooperation and cross-functional teams. In this regard, many hotels have created a distinct job title for solving the company's environmental issues. For example, Executive Director, Non-profit, Project Leader/Manager, Sustainability Program Director/Manager, sales/Business Development Associate or Manager, Marketing Manager/Coordinator, Community Crew Leaders/Supervisors, Conservation Associations, Business/Data Analyst, and Research Analyst/Manager. 


\section{Green Recruitment and Selection}

Generally, the process of determining, attracting, interviewing, choosing, hiring, and integrating workforce are referred to as recruitment. In other words, it covers everything from defining personnel requirements to filling them. In 2007, John Sullivan, a HR Specialist and Professor of Management at San Francisco State University's School of Business, coined the term "green recruitment." Moreover, Green recruiting is not a trend that will fade away. Organizations all across the universe are jumping on the green recruiting trend.

Then, came the study of (Nagrath and Gupta, 2013) who defined Green Recruitment as the practice of conveying a company's unwavering commitment to environmental causes with the applicants who are seeking to hire. (Ahmad, 2015) identified green recruitment as the process of recruiting employees who have the expertise, talents, attitudes, and behavioral patterns that are compatible with an organization's sustainability objectives.

Green recruitment is an important aspect of Green Human Resource Management Practices that emphasizes the significance of having a workforce who is concerned about ecological concerns, which can help them improve their environmental Performance (Zibarras and Coan, 2015). Then, (Urbaniak, 2015) referred to green recruiting as a procedure in which the candidate's awareness of environmentally issue and emotional desire to work for a green firm are highlighted.

Moreover, (Ahmad, 2015) affirmed that Companies can effortlessly recruit professionals who are knowledgeable of eco - friendly practices and are already acquainted with essentials like wastage, conservation, and developing a more reasonable world by recruiting candidates with a green bent of mind. In the recruitment framework, certain companies are integrating their organizational environmental objectives and practices with their recruitment process. From the workforce's perspective, also candidates are looking for and have a desire to work in corporations that are concerned about environmental issues.

Additionally, (Arulrajah, Opatha, and Nawaratne, 2016) stressed that organizations have realized that establishing an image as a green workforce is a good idea to attract new staff. Besides, the study emphasized that human resource representatives who are environmentally conscious can recruit the expertise they need to adopt green management practices, which helps them accomplish their organization's green objectives. Several organizations declare that they prefer to hire applicants with the green skills and green behaviors required to engage in organization's objectives environmental management practices. These are some of the green recruitment practices that a corporation can employ. (Arulrajah, Opatha, and Nawaratne, 2016) provide a set of traditional and innovative HRM practices in the context of green recruitment.

When sending recruitment messaging, indicating or making accessible the organization's environmental performance (past and current).

Becoming a green employer or a preferred green employer Environmental criterion should be included in recruitment communications.

Using recruitment efforts to communicate the employer's concern about environmental issues.

Incorporating the organization's environmental policies and strategies into its recruitment policy.

Incorporating particular environmental ideals (e.g., be a member of $\mathrm{ABC}$ 's green team or we are a socially and ecologically responsible employer) into the company's employment adverts.

In the recruitment message, express the organization's preference for individuals who have the skills and attitudes to participate in corporate environmental management activities.

Thereafter, came the study of (Tang, et al., 2018) who characterizes Green Recruitment and selection in three dimensions: applicant green awareness, green employer branding, and green hiring criteria. Firstly, applicant green awareness is the backbone of Green Recruitment and selection; it includes personality characteristics as if green scrupulousness, mindfulness, and agreeableness that help organizations accomplish their environmental objective. Therefore, Organizations should use a series of exams to recruit and select employees who are environmentally conscious, ensuring that all workforces are enthusiastic about ecological issues.

Secondly, green employer branding, can be pointed out a corporation's public image in concerning environmental management, which can be developed through Green Human Resource Management Practices. Furthermore, (Tang et al., 2018) mentioned in their work based on the work of Willness and 
Jones that through green employer branding, job applicants can reach a suitable match between their values and an organization's objectives, and they may have a feeling of euphoria working for a corporation with a solid ecological image. Consequently, green branding by human resource department (i.e., green employer branding) is an attractive way to recruit and choose potential employees who are concerned about environmental issues and attitudes.

Organizations can also employ marketing to highlight their green image, sustainability practices, and environmental regulation, which can assist entice individuals to apply for available positions (Chaudhary, 2018). Thereby, (Macalik and Sulich, 2019) confirmed that Employer branding is indeed one of the speediest fields in literature and business. Additionally, (Birou, Green, and Inman, 2019) mentioned that many businesses hire high-performing employees depending on their ecological efforts, which help them project a positive reputation in the community. Moreover, the work of (Pracodawcy, 2019) emphasized that strong. Human resources (HR) department that assists the top management of the organization not only in managing the workforce and creating the internal brand, but as well in developing the overall brand of the organization.

Thirdly, environmental criteria should be employed to appraise and select candidates. For example, as mentioned earlier, job descriptions and job specifications must contain green criteria, which are used for interviewing, nomination, and selection of applicants, thus the job analysis process serves the green recruitment process. Besides, green assimilation of HR specialists who are already conscious of environmental and eager to serve the community makes it easier to establish green practices that help organizations to meet their green targets. (Roscoe, Subramanian, Jabbour, and Chong, 2019)

In the light of that, the study of (Ghouri et al., 2020) discussed that in order to recruit potential workforce, environmental institutions must establish a public image and reputation as a green organization. Furthermore, green recruitment process outlines what is expected of potential green staff in the future and demonstrates green accomplishments and ecological concerns of firms. The process is considered as an application of the job analysis process (i.e., job description and job specification).

Additionally, (Martins et al., 2021) stressed that green recruitment resulted in the growth of a green workforce that consistently and professionally contributed to the organization's environmental objectives. Therefore, the study affirmed that to enhance efficiency and respect to environmental norms, employers must use green recruitment processes. Green recruitment has been related to the strengthening of environmental policies that promote to sustainability as well as an improvement in workforce loyalty to the organization. Green recruitment processes can be considered as the application of environmental management in the human resource management function of the organization to improve its efficiencies and lead to better environmental performance.

\section{Green Training and Development}

Initially, Stoughton and Ludema in 2012 stressed that the main objective of the green training is to convince and integrate environmental practices into the organization's mentality. (Ahmad, 2015) defined training and development as a process that aims to improve workforces' talents, expertise, and perspectives in order to avoid the spread of Environmental Management-related information, talent, and perspectives.

However, the researchers interpreted green training as a significant practice used by some green human resource department in green organizations. Through the training courses, these organizations can offer the required basic information and knowledge about their green management policies, strategy, and practices after selecting candidates for the positions. Besides, the work of (Arulrajah, 2015) who discussed the significance of green training in strengthening workforces' skills and talents in order to improve ecological concern.

Additionally, the work of (Mehta and Chugan, 2015) who emphasize that green training and development improves employees' environmental abilities, expertise, and mentality. Upon entering the company, workforces should embrace the company's green practices and objectives. Furthermore, green training and development teach workforce on the significance of Environmental Management, training them in energy-saving and end up wasting techniques, develop ecological consciousness within the organization, and offer opportunities for workforces to participate in ecological issue (Ahmad, 2015) based on study of (Zoogah, 2011) 
Moreover, (Ahmad, 2015) emphasized that the workforces become fully aware of multiple perspectives and the significance of ecological management through green training and development practices. As well as green training and development enables them to accept various preservation strategies, such as pollution reduction within a business. In addition, green training and development also improves an employee's ability to cope with a variety of ecological concerns.

Nowadays, organizations are interested in training that creates work teams who are passionate about green policies in effective management practices. Furthermore, employee who has received green training and guided practice ought to be ready to inform clients about the benefits of being increasingly environmentally conscious and purchasing green products. Thereafter, (Ljubljana, 2016) considered Green Training as a preliminary and introductory process for new hires that should include green seminars that will motivate workforces to identify the organization's green policies and practices, as well as to adapt to the organization's green targets and objectives.

The training process requires the preparation and evaluation of content that can help enable the necessary training courses in strong environmental management and through this the implementation of effective and integrated training programs. Several actions can be conducted by HR department to establish an integrated environmental training course. For example, reviewing previous training sources, HR capabilities and comparing employee brands.

Consequently, such actions means that the HR department needs to think about how to employ these capabilities and these brands, review job background, job description, and job specifications, and then merge them into the training process for new employees.

Therefore, workers and managers must be constantly up to date on a daily basis, and they must be convinced of the importance of achieving environmental goals as a whole in order for the process to be successful (Ljubljana, 2016). Moreover, the study of (Arulrajah, Opatha, and Nawaratne, 2016) stated that in terms of green training, organizations might choose one of two strategies. There are two types of green training: general green training and job-specific green training.

In that case, Organizations should make sure that new hires are aware of their green duties, are acquainted with health and safety policies, value the workplace green culture, and follow the green management policies and practices. Arulrajah, A., (Opatha, \& Nawaratne, 2016) provides some Existing Human Resources Management practices under the green training and development.

Inducing a general green state.

Providing green induction for certain jobs.

Making new employees aware of the organization's environmental activities and encouraging them to engage in green interpersonal citizenship behaviour.

Creating induction programmes that demonstrate current employees' green citizenship behaviour.

Therefore, Green training and education-integrated programs should be offered to all staff (i.e., employees and managers) of the organization, not only those associated with green divisions. Green training integrated programs can assist employees in becoming more aware of the organization's proenvironmental activities. Green training courses can help all workforces (i.e., employees and managers) comprehend the significance of ecological preservation, making them more responsive to green perspective; pollution protection and prevention practices such waste data collection and pollution source identification. Thus, this has been reflected in the internal situation and the way they use organizational resources (such as paper, electricity, as well as time).

Moreover, green training helps build an atmosphere that motivates all workforces to take an interest in environmental initiatives and ensure that they are beneficial and applicable and not just an ideal that is not applicable. It is important to realize that integrated training includes not only comprehensive programs but also complete with assessments and performance management systems, which are a way to create an ecological work climate. Thereafter, (Tang et al. 2018) considered three angles of green training: increasing awareness, managing knowledge, and improving the work climate. Firstly, green training can raise employee knowledge of pro-ecological workplace initiatives.

Secondly, Workforce can engage in ecological practices with the help of green training, which provides knowledge management. Workforces can obtain comprehensive green training through green knowledge management, strengthening their expertise and capabilities in ecological sustainability as well 
as their ability to deal with complicated ecologic challenges. Thirdly, Green training creates an atmosphere where all workforces are encouraged to participate in ecological projects. Additionally, as mentioned before, the way to create an environmental work climate through green training is that training should include comprehensive programs, assessments, and performance management systems.

Moreover, the study of (Othman and Mousa, 2019) that emphasized that green training is recognized as a top concern for any organization, as it is required for implementing effective ecological management and cleaner industrial operations. The study indicated that implementing an environmental framework in the workplace necessitates raising staff' abilities, consciousness, and expertise of both resources and processes; this, consecutively, necessitates green training to encourage staff commitment and involvement in environmental concerns.

Moreover, (Rahman et al., 2020) recommended a combination of green training and development practices, including workforce training in green workplace analysis, electricity efficiency, reduction and waste management, and human capacity improvement in environmental approaches and techniques. Job rotation concepts should be utilized as an important determinant of training and professional development strategies to achieve to achieve the goal of workforce participation in environmental problem-solving missions. Thus, organizations should make those opportunities available to the workforces.

Additionally, (Mukherjee et al., 2020) provided some of the green training and development practices that are commonly seen in organizations, such as ecological discussions in the training and development session. In addition, training employees in environmentally friendly behaviors such as commuting and recycling management, communicate the organization's sustainability goals to new employees, conduct an assessment of green training requirements, and the use of online learning materials.

Eventually, (Mata et al., 2021) affirmed that green training contributes to the improvement of an organization effectiveness. It assists the organization in strengthening the green competences of the workforce. Moreover, green training causes workforces to be content with their occupations. Green training suggests that businesses should not only train their workforce in best organizational practices with regard to green policies, but also inspire clients to be more conscious of the environment and support the practice of purchasing green products.

\section{Research Methodology}

In order to ensure the correct implementation of the research paper, the need for an appropriate methodology has emerged. Therefore, a literature review described the definition, application, and benefits of GHRM, and the various potential factors influencing the adoption of GHRM in organizations. The main purpose of this research is to investigate an overview of GHRM practices and their importance to the environment. Therefore, the research began with a theory related to green human resource management and practices such as green job analysis, green recruitment, and green training and development.

Then to clarify how these practices are contained in the organization, the researchers relied on the research published in this field from 2015 to 2021, and this is because from the researchers' point of view, the real interest in the environment began since 2015. The sustainable development goals (SDGs), also known as the Global Goals, were adopted by all United Nations Member States in 2015 as a universal call to action to end poverty, protect the planet and ensure that all people enjoy peace and prosperity by 2030 .

Research philosophy is concerned with the progress of knowledge and has major implications for how people perceive the environment. According (Saunders et al., 2009) There are four main philosophies: pragmatism, positivism, realism, and explanatory. Interpretivism, the newest study philosophy, suggests that it is essential for the future. In the role as social participants, researchers are trying to figure out how humans vary. Interpretivism proponents claim that the world is more complicated to construct rule generalization.

The research philosophy for this dissertation will be interpretivistic. In the field of green human resource management, this philosophy is suitable. Because the participants in the study have distinct qualities and each event is unique, the findings of our study cannot be generalised. The researchers will participate in and perform research using the qualitative research method. 


\section{Conclusion}

This paper discussed green human resource management practices in details. It mainly focused on green job analysis, green recruitment and selection, and green training and development, practices in organization. Therefore, the study confirmed that GHRM and its practices have a beneficial and significant impact on the long-term competitive advantage of Egyptian organizations. As a result, the conclusions of the study revealed the importance of human resource management department in implementing green practices within the organization. As a result, it is recommended that every organization located in Egypt adopt an environmentally friendly approach while also paying attention to the environment in which the company operates in order to be environmentally friendly and pollution free for the residents. It encourages employees to be environmentally conscious by promoting green behavior

The researchers interpret Green Human Resource Management Practices as the practices carried out by the organization in order to be supportive of the green perspective and achieve sustainable development, and this is what countries, and their organizations are striving for at the present time. Therefore, this goal can only be achieved by starting with the most important resources of the organization, which is the workforce, and then starting to influence their behavior and their affiliation with some practices such as green job analysis, green recruitment and selection, and green training.

Firstly, the researchers considered Green Job Analysis as the cornerstone that supports the rest of the practices (i.e., green recruitment and selection, and green training) and describing it as a primitive practice. The researchers explained green job analysis as a written framework for specifically defining the description of each job, this is called Job Description., It also lists the skills, and knowledge that the job needs in the applicant who will occupy this job, and this is called Job Specification.

Besides, job description and job specification are associated with the term "green" which is why they support the green perspective in all the details of explaining the techniques used in the job and how to do the job and also detailing the required skills. In addition, the researchers consider job analysis is an essential reference for both workforces and managers: workforces should be aware of the details and specifics of their job and their responsibilities towards it, while managers make use of it firstly to evaluate employees and then build upon it the rest of the green practices.

Secondly, the researchers expressed green recruitment and selection as a practice that seeks to create a group of employees who share a single interest, which is the preservation of the environment. Green recruitment and selection are done through three steps. The first is to set green criteria for interview and selection, the second step is to carry out the interview in a green way, for example, an online interview, and the third step choose the most suitable applicant from the green side with green knowledge and green skills.

Thirdly and finally, the researchers expressed Green Training as the practice that seeks to create an integrated green work atmosphere through well-thought-out integrated training programs for employees. Therefore, green training is done by working in two aspects. The first aspect is to train new employees on the required skills of the traditional job and the required green skills included in the green job. The second aspect is to train existing and old employees, including managers, so that they are not outdated and staying up to date.

\section{Limitations and direction for future research}

The only three green human resource management practices used in this study were green job analysis, green recruitment, and green training and development, this is not to indicate that Green human resource management is entirely made up of these three practices; there are more practices of green human resource management that can be investigated in future studies such as: green compensation and reward, green leadership management, and green performance management. Future research integrating strategic plan and employee participation could help to paint a true overview of Green human resource management`s inclusive impact on organizations.

Another limitation of this study is the generalizability of the conclusions about the institutional effects because there are other factors that affect each organization, such as (the age of the employees - the ability to change between managers - the province in which the company is located, and so on). Additionally, for all stakeholders, the future of GHRM appears bright. The researchers believe that GHRM should be 
integrated into the field of management, both academically and in practice, in order to close the gap in this area.

\section{References}

Augustine, E., Ejeje, E., John, O., RichaNsor, E., \& Nwuguru, M., 2021. Correlation Between Job Analysis and Corporate Performance of Business Organizations in Nigeria: A Study of Niger Mill Plc Calabar. International Journal of Entrepreneurship and Business Innovation, 4(1), pp.61-81.

Tsymbaliuk, S., Vasylyk, A. and Stoliaruk, K., 2021. Green human resource management: how to implement environmental issues into HR practices. E3S Web of Conferences, 255, pp.1-8.

Song, K., Kim, H., Cha, J. and Lee, T., 2021. Matching and Mismatching of Green Jobs: A Big Data Analysis of Job Recruiting and Searching. Sustainability, 13(7), pp.2-15.

Jamal, T., Zahid, M., Martins, J., Mata, M., Rahman, H., \& Mata, P., 2021. Perceived Green Human Resource Management Practices and Corporate Sustainability: Multigroup Analysis and Major Industries Perspectives. Sustainability, 13((1), pp.2-17.

Martins, J., Aftab, H., Mata, M., Majeed, M., Aslam, S., Correia, A., \& Mata, P., 2021. Assessing the Impact of Green Hiring on Sustainable Performance: Mediating Role of Green Performance Management and Compensation. International Journal of Environmental Research and Public Health, 18(1), pp.2-16.

Mousa, S., \& Othman, M., 2021. The impact of green human resource management practices on sustainable performance in healthcare organizations: A conceptual framework. Journal of Cleaner Production, pp.2-13.

Ghouri, A., Mani, V., Khan, M., Khan, N., \& Srivastava, A., 2020. Enhancing business performance through green human resource management practices: empirical evidence from Malaysian manufacturing industry. International Journal of Productivity and Performance Management, 69(8), pp.1585-1607.

Islam, M., Hunt, A., Jantan, H., Hashim, H., \& Chong, C., 2020. Exploring challenges and solutions in applying green human resource management practices for the sustainable workplace in the ready-made garment industry in Bangladesh. Journal of Business Strategy and Development, 3(1), pp.332-343.

Malik, S., Cao, Y., Mughal, Y., Kundi, G., Mughal, M., \& Ramayah, T., 2020. Pathways towards Sustainability in Organizations: Empirical Evidence on the Role of Green Human Resource Management Practices and Green Intellectual Capital. Journal of Sustainability, 12, pp.2-24.

Mukherjee, S., \& Bhattacharjee, S., 2020. Assessing Green Human Resource Management Practices in Higher Educational Institute. Journal of Test Engineering and Management, 82, pp.221 - 240.

Mohammad, N., Bibi, Z., Karim, J., \& Durrani, D., 2020. Green Human Resource Management Practices and Organizational Citizenship Behaviour for Environment: The Interactive Effects of Green Passion. International Transaction Journal of Engineering, Management, \& Applied Sciences \& Technologies, 11(6), pp. 2-10.

Saifuddin, Q., Hussain, F., \& Khan, I., 2020. Striving to Implement Green Human Resource Management (GHRM) Policies and Practices: A Study from HR Managers Perspective. International Journal of Management Excellence, 14(2), pp.2037-2048.

Dorcas, T., 2020. green human resource management and employees'sustainable performance: a study of dangote cement PLC. Journal of Oduduwa University, 18(1), pp. 29-48.

Cabral, C., \& Dhar, R., 2020. Green competencies: insights and recommendations from a systematic literature review. Benchmarking an International Journal, 1(1), pp.1-40.

Aykan, E., 2020. Gaining a Competitive Advantage through Green Human Resource Management. World's Largest Science, Technology \& Medicine, pp.160-165.

Hristova, S., \& Stevceska, D., 2020. Green HRM in pursuit of sustainable competitive advantage. University American College Skopje, 15(1), pp. 53-63.

Raut, R., Gardas, B., Luthra, S., Narkhede, B., \& Mangla, S., 2020. Analysing green human resource management indicators of automotive service sector. International Journal of Manpower, 41(8), pp. 4-20.

Morgan, D., \& Rayner, J., 2020. Development of a scale measure for green employee workplace practices. Journal of New Business Ideas \& Trends, 17(1), pp.1-22.

Benevene, P., \& Buonomo, I., 2020. Green Human Resource Management: An Evidence-Based Systematic Literature Review. Journal of Libera University, 12(1), pp.2-25.

Fathy, A., 2020. The role of green human resource practices in supporting sustainable development in universities. Journal of international conference of industrial and service organizations management in light of sustainable development plan, pp.1-47.

Zhang, Y., Luo, Y., Zhang, X., \& Zhao, J., 2019. What a Green Human Resource Management Can Promote Green Employee Behavior in China: A Technology Acceptance Model Perspective. Journal of Sustainability, 11(5408), pp.2-19. 
Phama, N., Tučkováa, Z., \& Jabbour, C. (2019). Greening the hospitality industry: How do green human resource management practices influence organizational citizenship behavior in hotels? A mixed-methods study. Tourism Management, 72(1), pp.386-399.

ROFI, M., 2019. Green Human Resource Management (Ghrm) Practices and Organizational Citizenship Behaviour for Environment (Ocbe): A Case of Fertilizer Company in Kedah. Journal of Universiti Utara Malaysia, pp.17-47.

Shariatpanahi, S., 2018. Testing and evaluating the new Safety Job Analysis (SJA) guidelines. Journal of University of Stavanger, pp.1-55.

Ren, S., Tang, G., \& Jackson, S., 2018. Green human resource management research in emergence: A review and future directions. Asia Pacific Journal of Management, 35(1), pp.769-803.

Zaid, A., Jaaron, A., \& Bon, A., 2018. The impact of green human resource management and green supply chain management practices on sustainable performance: An empirical study. Journal of Cleaner Production, 204(1), pp.965-979.

Tang, G., Chen, Y., Jiang, Y., Paille, P., \& Jia, J., 2018. Green human resource management practices: scale development and validity. Asia Pacific Journal of Human Resources, 56(1), pp.31-55.

Macalik, J., \& Sulich, A., 2017. external employer branding of sustainable organizations. International Scientific Conference, pp.2-13.

Mishra, P., 2017. Green human resource management A framework for sustainable organizational development in an emerging economy. International Journal of Organizational Analysis, 25(5), pp.762-788.

Kshatriya, S., 2016. Job Analysis and its Positive Impact on key Recruitment and Selection Processes: A Case Study. Al Dar Research Journal for Sustainability, 1(1), pp.1-23.

Millar, J., Sanyal, C., \& Camen, M., 2016. Green human resource management: a comparative qualitative case study of a United States multinational corporation. The International Journal of Human Resource Management, $27(2), 192-211$.

Ahmad, S., 2015. Green Human Resource Management: Policies and practices. Cogent Business E Management, 2(1), pp 2-13.

Arulrajah, A., Opatha, H., \& Nawaratne, N., 2015. Green Human Resource Management Practices: A Review. Journal of Human Resource Management, 5(1), pp.2-16.

Ahmad, S., 2015. Green Human Resource Management: Policies and practices. Cogent Business E Management, 2(1), pp.2-13.

Arulrajah, A., Opatha, H., \& Nawaratne, N., 2015. Green Human Resource Management Practices: A Review. Journal of Human Resource Management, 5(1), pp.2-16.

Wijayani, A., 2015. Redesign Process of Job Analysis and Job Satisfaction: A Qualitative Study on The Combined Group on Farmer. Journal Dinamika Manajemen, 6(2), pp.197-206.

Fayyad, S., Abdel Hadi, A., Ahmed, M., \& Ibrahim, S., 2013. A study on green hotels in Egypt. Journal of The Association of Arab Universities for Tourism and Hotels, 10(1), pp.2-18.

Rehman, M., 2010. Impact of Job Analysis on Job Performance: A Study of Public Sector Organizations of Pakistan. Journal of National University of Modern Languages, pp.29-40. 